\title{
TRAGEDI INTELEKTUALITAS ISLAM DALAM PERSPEKTIF FILSAFAT POLITIK-KEAGAMAAN (STUDI KASUS NAKBAH IBNU RUSYD DAN PEMBUNUHAN FARAQ FOUDA)
}

\author{
Oleh: \\ Ario Putra ${ }^{1,}$ Achmad Fatturohman ${ }^{2}$ \\ Aqidah dan Filsafat Islam, Pascasarjana UIN Sunan Kalijaga Yogyakarta \\ arioputra1996@gmail.com ${ }^{1}$ \\ Fathurrohman@ tebuireng.net ${ }^{2}$
}

\begin{abstract}
The differences that occur sometimes often lead to violence and even end in murder. Islam as a religion that is rahmatan lil 'alamin highly upholds human values, tolerance, and differences. Therefore, Muslims should understand them as fundamental religious values contained in the Qur'an and Sunnah, in order to form a good and peaceful life order. The method used in this research is descriptive-explorative. This research is a library research (Library Research), while the data collection method in this research is by classifying the data related to the research focus, then analyzing it. The findings in this study are that although Islam is a religion that is rahmatan lil 'alamin, in reality it has not been fully realized because throughout its history of development there are still various tragedies and conflicts in Islam. One of them is intellectual tragedy. This tragedy is not due to religious factors, but from the way Muslims are still unable to understand religion properly so that from this lack of understanding emerges intolerant traits and even these traits sometimes lead to murder. One of the tragedies contained in Islam is the intellectual tragedy of the Nakba Ibn Rushd and the tragedy of the murder of Faraq Fouda.
\end{abstract}

Keywords: Intellectual Tragedy, Nakbah Ibn Rushd, Faraq Fouda.

\section{A. PENDAhULUAN}

Islam sebagai agama yang rahmatan lil 'alamin, sangat menjunjung tinggi nilai-nilai kemanusiaan, serta nilai-nilai kebaikan atas seluruh makhluk ciptaan Tuhan. Islam sebagai agama tidak hanya membahas serta memusatkan perhatian kepada Tuhan saja, akan tetapi juga membahas tentang segala persoalan-persoalan yang dihadapi manusia. Oleh karena itu Islam dikatakan sebagai shalih li kulli al-zaman wa al-makan.

Pada dasarnya semua agama menginginkan kebaikan atas seluruh makhluk tanpa terkecuali, akan tetapi pada kenyataannya masih banyak ditemukan segala bentuk kekerasan, baik kekerasan wacana seperti memberikan stereotipe ataupun memberikan label kafir, sesat, bid'ah 
dan penista agama kepada yang lain. Serta kekerasan dalam bentuk fisik seperti pembunuhan, pemukulan, pembakaran tempat ibadah, penganiayaan dan lain sebagainya (Wijaya, 2018, 1) Kekerasan yang terjadi acapkali dilakukan dengan mengatasnamakan Tuhan atau agama, pada hal agama sejatinya menyuruh dan mengajarkan kebaikan dan sikap saling menjaga antar sesama.

Sebagaimana diungkapkan oleh Samuel P. Huntington yang dikutip oleh Fahruddin Faiz, bahwasanya suatu perbedaan yang terjadi tidak harus melahirkan konflik, dan konflik tidak harus berarti kekerasan (Faiz, 2012, 2) Akan tetapi realitas sejarah yang berkembang berbanding terbalik dengan ungkapan tersebut.

Perbedaan yang melahirkan konflik dalam Islam tidak hanya terjadi pada masa sekarang, akan tetapi telah terjadi sejak masa-masa awal Islam. Jika melihat sisi historis Islam, maka perbedaan yang terjadi pada masa awal seperti perbedaan dalam penafsiran Al-Qur'an dan hadis, perbedaan dalam persoalan fiqih yang kemudian memunculkan mazhab-mazhab, perbedaan dalam keragaman interpretasi teologis dan filosofis yang menjadi cikal bakal munculnya aliran-aliran dalam teologi dan filsafat serta perbedaan dalam interpretasi politik yang berbasis teks-teks religius. Perbedaan-perbedaan yang terjadi terkadang menimbulkan perpecahan di kalangan umat Islam bahkan kadangkala perbedaan tersebut menjurus pada peperangan (Nasr, 2003, 10)
Kekerasan yang terjadi dengan mengatasnamakan Tuhan dan agama yang kemudian memunculkan sikap saling mengkafirkan, menyesatkan bahkan saling membunuh di antara penyebabnya adalah pemahaman terhadap persoalan al-firqah alnajiyah (golongan yang selamat). Pemahaman yang diyakini tersebut kemudian memunculkan pemikiran bahwa golongan mereka adalah yang benar sebagaimana disabdakan oleh Nabi dan golongan yang berbeda dari mereka merupakan golongan yang sesat bahkan termasuk golongan kafir (Hanafi dan Al-Jabiri, 2015, 36)

Selain itu, penyebab lain munculnya kekerasan yang mengatas namakan Tuhan dan agama juga didasari oleh cara mereka dalam menalar Islam dan memahami nalar ke-Islaman dengan landasan ideologi. Apabila cara menalar Islam membantu mereka dalam memahami Islam dengan benar maka nalar keIslaman yang berlandaskan ideologi membuat mereka meyakini bahwa cara memahami Islam yang paling benar ialah dengan mengikuti cara mereka dalam memahami dan meyakininya. Sehingga nalar keIslaman yang mengideologi tersebut akhirnya disakralkan. Pemikiran keIslaman yang sudah disakralkan membuat mereka semakin yakin akan kebenaran pemikiran tersebut, sembari menolak semua bentuk kebenaran pemikiran yang lain. Dan bagi mereka, pemikiran yang tidak sejalan dengan pemikiran ke-Islaman mereka dinilai tidak sejalan dengan Islam (Wijaya, 2018, 2-3)

Di antara berbagai perbedaan yang menimbulkan kekerasan atau 
yang menyebabkan tragedi intelektual dalam Islam yaitu tragedi nakbah yang dialami oleh Ibnu Rusyd dan tragedi pembunuhan yang terjadi kepada Faraq Fouda. Oleh karena itu, dalam penelitian ini penulis berusaha untuk mengungkapkan serta menelusuri lebih mendalam terkait kedua tragedi intelektual yang terjadi dalam Islam sebagaimana yang telah disebutkan di atas. Penulis melihat, penting untuk mengungkapkan kembali bagaimana sejarah perkembangan Islam dalam sisi intelektual yang kemudian menghadirkan berbagai trageditragedi yang terjadi.

Setelah melihat permasalahan yang dipaparkan di atas, maka fokus penelitian ini adalah Bagaimana tragedi intelektual yang terjadi dalam Islam ? serta bagaimana tragedi intelektual nakbah yang terjadi kepada Ibnu Rusyd dan tragedi pembunuhan terhadap Faraq Fouda ?

Penelitian ini bertujuan untuk memberikan sumbangsih pengetahuan bagi perkembangan akademik terkait permasalahan tragedi intelektual dalam Islam. Dengan penelitian ini juga diharapkan dapat menjadi solusi atas permasalahan yang bersumber dari perbedaan-perbedaan agar ke depan tidak terjadi kekerasan yang sama. Perbedaan merupakan suatu hal yang lumrah dalam kehidupan dan perbedaan tidak mesti menimbulkan suatu kekerasan.

\section{B. Metode Penelitian}

Jenis penelitian ini merupakan penelitian kepustakaan (Library research), adapun metode yang digunakan dalam penelitian ini bersifat deskriptif-eksploratif, penelitian deskriptif merupakan penelitian yang bertujuan untuk menggambarkan atau mendeskripsikan secara jelas terhadap permasalahan yang diteliti. Sedangkan eksploratif yaitu suatu metode yang berfungsi untuk memperdalam khazanah intelektual atau untuk mendapatkan ide-ide baru dalam suatu penelitian.

\section{PEMBAHASAN \\ 1. Tragedi Intelektual dalam Islam}

Tragedi dalam pengertiannya yaitu suatu kisah atau peristiwa sedih yang dialami oleh seseorang ataupun sekelompok masyarkat. Dalam suatu tragedi, tokoh ataupun pelaku utama acapkali mengalami penderitaan, kesengsaraan dan bahkan dapat berujung pada kematian. Oleh karena itu, penyebutan kata tragedi selalu menunjukan kepada peristiwa yang bernuansa kesedihan ataupun nuansa penderitaan.

Sedangkan defenisi intelektual adalah manusia yang sangat berbakat dan diberkahi moral filsuf-raja. Tugas para intelektual yaitu untuk membangun kesadaran umat manusia menuju kepada yang lebih baik. Para intelektual sejati pada dasarnya melakukan sesuatu bukan untuk mencapai suatu tujuan praktis, melainkan untuk mendapatkan kepuasaan dalam mempraktekkan seni ataupun ilmu pengetahuan (Said, 2014, 2) Berdasarkan defenisi di atas dapat disimpulkan bahwa tragedi intelektual dalam Islam yaitu suatu 
peristiwa yang berujung pada penderitaan, kesengsaraan ataupun pembunuhan terhadap tokoh Islam yang memiliki kecerdasaan tinggi dan sangat berbakat.

Tragedi intelektual dalam Islam tidak hanya berupa peristiwa yang dialami oleh individu, akan tetapi juga dapat terjadi pada suatu masyarakat, seperti peristiwa mihnah Mu'tazilah yang menjadi tragedi intelektual yang dialami oleh masyarakat Islam. Mihnah merupakan suatu peristiwa pemeriksaan terkait pandangan tentang kemakhlukan Al-Qur'an (Amin, 1936, 166) Menurut kelompok Mu'tazilah, al-Qur'an (kalam Allah) itu bersifat baharu, karena kalam Allah tersebut terdiri dari huruf, suara, dan semua itu dapat ditiru yang kemudian hal seperti demikian dapat hilang (AsySyahrastani, 2003, 38) Oleh karena itu, apabila masyarakat tidak meyakini bahwa Al-Qur'an bersifat baharu dan menganggap Al-Qur'an bersifat qadim maka keyakinan tersebut dianggap syirik, dan harus diluruskan meskipun dengan jalan kekerasan (Amin, 1936, 166)

Selain itu, tragedi intelektual juga dialami oleh Ibnu Taimiyah. Ibnu Taimiyah berulang kali ditangkap oleh penguasa, karena selalu mengeluarkan pendapat dan pemikiran yang bertentangan dengan masyarakat serta dengan para penguasa. Meskipun berada dalam penjara akan tetapi itu tidak mengurangi semangat menulis Ibnu Taimiyah (Thaha, 1982, 18) hingga akhirnya Ibnu Taimiyah meninggal di dalam penjara bertepatan pada tanggal 26 September 1328 atau pada hari senin 20 Dzulqaidah $728 \mathrm{H}$ (Ahmad, 2005, 263)

$\begin{array}{clr}\begin{array}{c}\text { Apabila } \\ \text { mendalam }\end{array} & \text { ditelusuri } & \text { lebih } \\ \text { dalam } & \text { sejarah }\end{array}$ perkembangan Islam, akan ditemukan lebih banyak bentuk-bentuk kekerasan intelektual yang kemudian menjadi suatu tragedi Intelektual dalam Islam. Penjelasan tentang tragedi intelektual di atas hanya sebagian dari kasus-kasus yang terjadi. Masih terdapat beberapa kasus serupa seperti kasus pengasingan Abu Hayyan al-Tawhidi, Saifuddin al-Amidi, al-Baidhawi, Ibnu Qayyim dan lain sebagainya. Semua penderitaan ataupun tindakan kekerasan yang dialami oleh tokohtokoh intelektual pada dasarnya disebabkan oleh aktifitas dan pemikirin mereka yang bertentangan dengan para penguasa ataupun dengan para tokoh-tokoh agama di zaman itu.

Berdasarkan penjelasan di atas dapat diketahui bahwa dalam perkembangan Islam terdapat berbagai bentuk tragedi yang menimpa umat Islam, tragedi tersebut terjadi dalam bentuk kekerasan, penganiayaan bahkan berujung pada pembunuhan. Meskipun Islam menjadi agama yang rahmatan lil 'alamin namun dalam penerapannya dalam kehidupan sosial masih belum terwujud secara keseluruhan, itu terbukti dari munculnya berbagai kekerasan yang dilakukan oleh oknum-oknum dalam Islam sendiri.

\section{Tragedi Nakbah Ibnu Rusyd}


Nama lengkap Ibnu Rusyd adalah Abu al-Walid Muhammad ibnu Ahmad ibnu Muhammad ibnu Rusyd (Fitrianah, 2018, 16) Ibnu Rusyd dilahirkan di Cordova, Spanyol pada tahun $520 \mathrm{H} / 1126 \mathrm{M}$ (Urvoy, 2000, 52) Ibnu Rusyd merupakan seorang filosof keturunan sarjana dan fukaha terkemuka di Spanyol (Fakhry, 1986, 374) kakeknya yang bernama Abu alWalid Muhammad al-Jadd dan ayahnya Abu al-Qasim Ahmad merupakan hakim terkemuka pada saat itu (Nasr dan Leaman, 2003, 414) Di kalangan sarjana Barat, nama Ibnu Rusyd lebih dikenal sebagai Averrois. Kata averrois merupakan refleksi dari terjadinya metamorfose dalam penyebutan kata Rusyd dalam Yahudi-Spanyol-Latin (Madjid, 1997, 94-95) Ibnu Rusyd lahir empat tahun setelah khalifah Bani Muwahiddun yaitu Muhammad bin Tumart meninggal dunia (Halimatuzzahro, 2017, 82)

Ibnu Rusyd tumbuh dan berkembang dalam keluarga yang sangat mencintai ilmu pengetahuan, hal tersebut terbukti ketika Ibnu Rusyd memberikan revisi terhadap karya Imam Malik, al-Muwatha, yang dipelajarinya bersama ayahnya (Faturohman, 2016, 111) Selain itu Ibnu Rusyd juga mempelajari matematika, fisika, astronomi, logika, filsafat dan kedokteran (M.M Syarif, 1991, 198) Di samping itu, Ibnu Rusyd juga memiliki ketajaman dalam berpikir dan memiliki otak yang sangat jenius (Mubit, 2016, 135)

Ibnu Rusyd merupakan sosok yang sangat luar biasa dan mengagumkan, karena hampir seluruh hidupnya ia dedikasikan untuk belajar dan membaca, bahkan dalam salah satu riwayat dikatakan Ibnu Rusyd tidak pernah belajar dan membaca kecuali pada malam ayahnya meninggal dan pada malam pernikahannya (Zar, 2014, 228) Sebagaimana diketahui bahwa Ibnu Rusyd menguasai berbagai disiplin ilmu pengetahuan, akan tetapi yang membawanya menjadi sosok yang popular dan terkenal di antara yang lain pada masa itu ialah melalui gagasan-gagasannya dalam bidang filsafat. Dengan filsafat juga ia menjadi dekat dengan penguasa seperti Abu Ya'qub Yusuf bin Abdul Mukmin dan anaknya Ya'qub alManshur (Anwar, 2019, 29) Pemikiran dan gagasan-gagasannya yang membuat Ibnu Rusyd menjadi ulama sekaligus filosof yang tak tertandingi (Drajat, 2006, 73)

Selain menjadi seorang filosof, Ibnu Rusyd juga pernah menjadi pejabat negara, yaitu sebagai Ketua Mahkamah Agung, guru besar, dan dokter Istana menggantikan Ibnu Thufail yang sudah tua. Meskipun menjabat di beberapa bidang, itu semua tidak menghalangi Ibnu Rusyd untuk terus menulis, bahkan Ibnu Rusyd sangat produktif dengan karya-karya ilmiah dalam beberapa bidang ilmu pengetahuan, dan karyakarya Ibnu Rusyd juga menjadi rujukan pada setiap bidangnya oleh para ahli. Hal ini merupakan indikasi keluasan wawasan dan kedalaman ilmu Ibnu Rusyd (Zar, 2014, 229)

Mengenai karya Ibnu Rusyd, para ahli sejarah berbeda pendapat akan jumlah pastinya (Madani, 2017, 
44) Ada pendapat yang mengatakan bahwa jumlahnya 78 karya yang mencakup segala bidang. Dan juga terdapat riwayat yang mengatakan jumlah karya Ibnu Rusyd 28 buku tentang filsafat, lima buku tentang teologi, delapan buku tentang fiqh, empat buku tentang astronomi, dua buku tata bahasa Arab, dan sepuluh buku tentang kedokteran (Khan, 2004, 108) Sedangkan karya-karya penting dari Ibnu Rusyd berupa buku Al-Kasyf 'an Manahij al-Adillat fi 'Aqa'id al-Millah, Fashl al-Maqal fi ma Baina al-Hikmah wa al-Syari'ah min al-Ittishal, Tahafut al-Tahafut, Bidayat al-Mujtahid wa Nihayat alMuqtashid (Zar, 2014, 231)

Jika ditelusuri lebih jauh, Ibnu Rusyd merupakan seorang pengarang yang produktif, Ibnu Rusyd menghasilkan berbagai karya dalam bidang disiplin ilmu pengetahuan, hanya saja karya Ibnu Rusyd tersebut tidak dapat ditemukan lagi karena sebagian telah hilang bahkan dibakar akibat tragedi yang menimpa dirinya. Selain itu juga terdapat tragedi lain yang menjadi faktor hilang atau musnahnya karya-karya Ibnu Rusyd, yaitu tragedi jatuhnya Andalusia ke tangan Ferdinant II dan Isabella. Kemenangaan tersebut membuat Jenderal Ximenes membakar habis semua buku yang berbau Arab ataupun berbahasa Arab (Zar, 2014, 231)

Sebagaimana dijelaskan di atas, bahwasanya Ibnu Rusyd merupakan seorang tokoh intelektual terkemuka pada saat itu bahkan sampai saat sekarang. Pemikirannya yang tertuang dalam karya-karyanya masih menjadi rujukan dalam beberapa disiplin ilmu pengetahuan. Ibnu Rusyd dapat dikatakan sebagai tokoh intelektual muslim yang sangat berpengaruh di dunia Islam maupun di kalangan Barat.

Meskipun Ibnu Rusyd menjadi tokoh intelektual yang berpengaruh dan dihormati, serta memiliki kedekatan dengan penguasa saat itu, namun nyatanya itu semua tidak dapat membantu Ibnu Rusyd terhindar dari berbagai perlakuan buruk yang diberikan oleh para tokoh agama bahkan ia juga mendapatkan perlakuan yang tidak pantas dari penguasa pada saat itu (Mashar, 2013, 81) Perlakuan tersebut kemudian dikenal sebagai tragedi nakbah.

Tragedi nakbah terjadi dilatarbelakangi oleh penentangan para tokoh agama dan penguasa terhadap gagasan ataupun pemikiranpemikiran Ibnu Rusyd. Hal tersebut dapat dilihat dari maklumat yang dikeluarkan oleh Ya'qub al-Manshur yang kemudian disebarluaskan mulai dari Cordova hingga ke seluruh wilayah kekuasaannya. Isi maklumat tersebut antara lain berbunyi:

"Dahulu, terdapat sekelompok manusia yang tenggelam dalam lautan khayalan, mereka dapat menyeret banyak orang yang tidak waspada ke dalam pikiran-pikiran mereka. Mereka menghasilkan karya yang kurang berguna. Isi dari bukubuku mereka itu jauh dari ketentuanketentuan syariat Islam seperti jauhnya jarak antara timur dan barat, mereka mengatakan kepada orang lain bahwa karya-karya tersebut merupakan hasil dari penalaran dan 
kebenaran akal. Di antara para penulis tersebut terdapat jin yang berwujud manusia, mereka lebih berbahaya dari golongan-golongan ahli kitab, karena ahli kitab berijtihad dalam sebuah kesesatan sedangkan mereka berijtihad demi ketidakpercayaan. Mereka kini telah bertebaran di segala penjuru, hingga akhirnya Allah memberi petunjuk para tokoh lain yang ditakdirkan oleh waktu untuk menghadapi gempuran dahsyat mereka. Semoga Allah senantiasa memberi kalian kehormatan, serta menganggap mereka sesuai dengan dugaan kami. Kami juga mengajak mereka untuk kembali kepada sikap yang dapat mendekatkan diri kepada Allah Azza wa Jalla (Al-Jabiri, 2003, 218-219)"

Apabila melihat isi dari maklumat di atas, maka dapat disimpulkan bahwa khalifah Ya'qub al-Manshur melakukan suatu upaya penentangan terhadap para filosof dan juga terhadap karya-karya filsafat. Namun hal tersebut menimbulkan suatu keanehan mengingat Ya'qub al-Manshur dan ayahnya Abu Ya'qub Yusuf bin Abdul Mukmin merupakan sosok yang sangat menggemari filsafat dan bahkan memiliki perpustakaan filsafat yang besar.

Meskipun dituduh sebagai karya yang kurang berguna dan dianggap jauh dari ketentuan-ketentuan syariat Islam, namun nyatanya pemikiran Ibnu Rusyd berusaha memberikan sebuah relasi antara agama dan filsafat. Menurut Ibnu Rusyd:

"berfilsafat dapat dipahami sebagai penalaran tehadap segala yang maujud, dan memandangnya sebagai bukti adanya pencipta. Segala yang maujud merupakan suatu ciptaan, sehingga mengetahui ciptaan dapat memberi petunjuk pada keberadaan Pencipta-nya. Semakin sempurna pengetahuan tentang ciptaan, maka akan semakin sempurna pula pengetahuan tentang Sang Pencipta. Sedangkan syari'at mendorong serta menuntut kita untuk mengetahui segala yang ada dengan menggunakan akal. Dorongan ini ditunjukan oleh berbagai ayat AlQur'an. Oleh karena itu dapat disimpulkan bahwa sunnah atau wajib hukumnya mempelajari filsafat (Rusyd, 2015, 35) Selain itu bagi Ibnu Rusyd "filsafat merupakan teman sekaligus saudara angkat bagi syari'at, sehingga kesusahan yang dialami oleh para filosof menjadi kesusahan pula bagi syari'at, termasuk munculnya permusuhan, kebencian, dan perselisihan di antara keduanya. Secara alamiah, kedua disiplin keilmuan itu berteman dan saling mencintai (Rusyd, 2015, 85)

Kemudian pada bagian maklumat berikutnya, Ya'qub alManshur menyatakan bahwa:

"Karena Allah menghendaki untuk menunjukan akan kebutaan mereka dan menyingkap kesesatannya, mereka dihentikan untuk tidak terus menulis berbagai kesesatan dan harus dirampas dari penulisnya tanpa harus permisi. Tulisan-tulisan mereka yang secara lahir dibalut dengan Kitab Allah namun bathinnya justru menyerukan agar berpaling dari Allah. Dengannya, keimanan telah terselimuti oleh kegelapan. Dengan 
tulisan-tulisan tersebut, mereka datang untuk menyerang namun berlagak bagai orang yang menyerah ketika kalah. Bisa beracun telah tersebar di segenap kegelapan. Membuka peluang kaum salib menyerang tanpa perlawanan. Mereka tampak secara lahir (baik ucapan maupun pakaian) seperti kebanyakan orang lain, tetapi sebenarnya bathin mereka sama sekali berbeda yang disebabkan oleh kesesatan dan dusta mereka. Setelah kami teliti kotoran yang menempel pada kelopak agama, titik hitam yang melekat pada cahaya yang benderang maka (semata karena Allah) kami campakkan mereka seperti kami mencampakkan biji tanaman. Dan juga kami buang orang-orang tolol tersebut. Semata karena Allah, kami membenci mereka, sebagaimana juga (semata karena Allah) kami mencintai orang-orang yang beriman (Al-Jabiri, 2003, 219-220)"

Selain itu, terjadinya tragedi nakbah juga berasal dari tuduhan yang dilontarkan oleh musuh-musuh Ibnu Rusyd, sebagaimana dijelaskan oleh Aksin Wijaya dalam "kata pengantar" Fashl al-Maqal fi ma Baina al-Hikmah wa al-Syari'ah bahwa "para rival dan juga musuh Ibnu Rusyd menemukan sebuah ungkapan dalam salah satu bukunya yang berkaitan dengan filsafat Yunani yang dinilai menyeleweng, ungkapan tersebut ialah sungguh telah jelas bahwa al-Zahrah adalah salah satu Tuhan. Kemudian diadakanlah sebuah forum pengadilan terbuka yang dihadiri oleh seluruh pelajar, ahli fiqh dan tokoh agama. Ketika Khalifah Ya'qub al-Manshur meminta Ibnu Rusyd untuk membuktikan persoalan tersebut, Ibnu Rusyd mengingkari pernyataan itu ada di dalam bukunya. Setelah itu Ibnu Rusyd dituduh telah kafir (Rusyd, 2015, 6)"

Kemudian setelah berbagai tuduhan tersebut, Khalifah Ya'qub alManshur kembali mengeluarkan maklumat yang berisi himbauan kepada para ulama dan masyarakat awam, yang isinya:

"Jagalah keimanan kalian dari sekelompok kecil ini seperti kalian mewaspadai racun yang mengalir ke tubuh kalian. Barangsiapa yang menemukan buku-buku mereka, maka balasannya adalah api yang juga akan membakar para pemilik buku tersebut. Kepada api itu pula para penulis dan pembaca buku tersebut akan kembali. Allah akan membersihkan kalian dari kotoran mereka yang anti Tuhan, Allah juga akan mencatat keberpihakan kalian pada kebenaran dalam daftar orangorang baik, dan sesungguhnya Allah Maha pemberi nikmat dan Maha Mulia (Al-Jabiri, 2003, 220)"

Selain itu salah satu penyebab terjadinya tragedi nakbah Ibnu Rusyd yaitu karena Khalifah Ya'qub alManshur marah kepada Ibnu Rusyd karena ketika ia sedang berbicara di hadapan masyarakat, Ibnu Rusyd memotong pembicaraan Khalifah dengan berkata "izinkan aku bicara wahai saudaraku (Rusyd, 2015, 5)". Sedangkan riwayat lain mengatakan bahwa penyebab terjadinya tragedi nakbah yaitu karena Ibnu Rusyd dituduh telah mengatakan Khalifah sebagai Raja Barbar (Malik AlBarbar) padahal yang ditulis oleh 
Ibnu Rusyd ialah Malik al-Barrain (Raja dua daratan: Afrika dan Eropa). Dalam bahasa Arab kedua kalimat tersebut memang memiliki kemiripan (Zar, 2014, 230)

Keterangan pasti penyebab dari tragedi nakbah dan keluarnya maklumat dari Khalifah Ya'qub alManshur masih menjadi permasalahan yang belum dapat dipecahkan, karena para ahli sejarah masih belum menemukan keterangan pasti terkait tragedi tersebut. Namun menurut Muhammad 'Abid al-Jabiri, informasi dan keterangan yang diberikan oleh Abdul Wahid alMarakisyi dalam bukunya yang berjudul al-Mu'jib Fi Talkhisi Akhbari al-Magrib dipercaya sebagai pemberi informasi terpenting dan terpercaya serta memiliki keautentikan sejarah. Hal tersebut karena Abdul Wahid al-Marakisyi hidup semasa dengan Khalifah Ya'qub al-Manshur, ia juga bersahabat dengan para gubernur, menteri, dan ulama daulah pada pada saat itu. Di antara gubernur yang bersahabat dengannya yaitu Abu Yahya, ia merupakan adik alManshur (Al-Jabiri, 2003, 232)

Menurut Abdul Wahid alMarakisyi, "pada masa pemerintahan Ya'qub al-Manshur, Ibnu Rusyd mendapatkan musibah yang berat, musibah tersebut bermula ketika Ibnu Rusyd memberikan komentar atas karya Aristoteles tentang binatang. Dalam memberikan komentar tersebut, Ibnu Rusyd juga mengedit, meringkas kandungan maknanya dan juga memberikan penjelasan yang diperlukan. Kemudian pada bagian pasal yang menguraikan tentang jerapah, reproduksi dan pengembangbiakannya, Ibnu Rusyd menyatakan saya pernah melihat binatang tersebut (jerapah) di istana Raja barbar. Ungkapan tersebut menjadi kelalaian dan kecerobohan Ibnu Rusyd. Setelah itu, pihak-pihak yang tidak menyukai Ibnu Rusyd dari kelas elit masyarakat Cordova berupaya menjatuhkan martabatnya di mata Khalifah Ya'qub al-Manshur. Upaya yang dilakukan oleh mereka yaitu dengan cara mengutip berbagai hasil ringkasan buku yang dilakukan oleh Ibnu Rusyd terkait filosof klasik. Setelah menelusuri karya-karya komentar Ibnu Rusyd mereka kemudian mendapatkan sebuah pernyataan tampaknya bahwa bunga itu merupakan salah satu dari para dewa. Kemudian mereka membawa lembaran ungkapan tersebut kepada Khalifah Ya'qu al-Manshur. Setelah menerima lembaran tersebut, Khalifah Ya'qub al-Manshur kemudian menghadirkan sejumlah tokoh terkemuka dari setiap lapisan masyarakat Cordova serta juga turut menghadirkan Ibnu Rusyd. Setelah Ibnu Rusyd datang ke forum pengadilan tersebut, Khalifah Ya'qub al-Mashur melemparkan lembaran ke hadapan Ibnu Rusyd seraya berkata "apakah ini tulisan kamu?" Ibnu Rusyd kemudian menyangkalnya. Lalu Khalifah Ya'qub berkata "Allah mengutuk pemilik tulisan ini dan menyuruh para hadirin turut mengutuknya pula. Kemudian, Khalifah memerintahkan Ibnu Rusyd meninggalkan ruangan dengan tidak hormat (Al-Jabiri, 2003, 233-234)

Tipu daya yang dilancarkan oleh kaum agamawan dan elite masyarakat untuk menjatuhkan Ibnu Rusyd itu 
berhasil (M.M Syarif, 1991, 203) Hal tersebut dapat terbukti ketika setelah pertemuan tersebut, Khalifah Ya'qub langsung memerintahkan untuk membuang serta mengasingkan Ibnu Rusyd bersama dengan mahasiswamahasiswa filsafat dan ilmu eksakta ke Lucena yang merupakan sebuah kota kecil di sebelah Selatan Cordova yang dihuni oleh orang-orang Yahudi (Fakhry, 1986, 375) Selain itu Khalifah juga mencopot segala jabatannya dan memerintahkan untuk membakar buku-buku karya Ibnu Rusyd kecuali yang bersifat ilmu pengetahuan murni (sains), seperti kedokteran, matematika dan astronomi (Zar, 2014, 230) Setelah perintah pembuangan dan pengasingan tersebut, Ibnu Rusyd selalu dihina dan disindir. Beberapa contoh hinaan itu dilontarkan oleh alAnshari, ia menggambarkan Ibnu Rusyd sebagai mutafalsif (filosof menit) selain itu juga sebagai mutazindiq (orang yang percaya pada bid'ah). (Urvoy, 2000, 60)

Latar belakang terjadinya tragedi nakbah Ibnu Rusyd juga tidak terlepas dari sisi politis, hal tersebut sebagaimana diungkapkan oleh Aksin Wijaya dalam pengantar "Nalar Agama dan Nalar Filsafat" bahwa, "pada waktu itu, sebenarnya Khalifah Ya'qub al-Manshur sangat mendorong kajian-kajian filsafat meskipun kajian filsafat sangat ditentang oleh para tokoh agamawan. Akan tetapi dorongan ini tidak mungkin dilanjutkan ketika Khalifah melakukan penyerangan terhadap kekuasaan Kristen di Spanyol, karena pada dasarnya penyerangan tersebut sangat membutuhkan dukungan dari tokoh-tokoh agama Islam di negara tersebut. Tindakan penindasan terhadap para filosof merupakan salah satu tindakan berani yang terpaksa dilakukan oleh Khalifah Ya'qub al-Manshur untuk mendapatkan simpati para tokoh agama Islam yang menentang filsafat, ditambah lagi dengan kondisi kaum muslim Andalusia yang sangat memusuhi filsafat dan para filosof. Hal ini diperkuat oleh fakta yang menunjukan bahwa tak lama kemudian, setelah Khalifah Ya'qub kembali dengan membawa kemenangan ke Maroko, ia memanggil Ibnu Rusyd ke istananya dan menyambutnya dengan penghormatan dan pemuliaan. (Rusyd, 2015, 7)

Dua atau tiga tahun dalam pengasingan kemudian Khalifah Ya'qub memanggil Ibnu Rusyd ke Marrakesh (Nasr dan Leaman 2003, 419) Dan mencabut hukumannya serta posisinya direhabilitasi kembali. Namun tidak lama setelah pencabutan hukuman tersebut, Ibnu Rusyd kemudian meninggal tepatnya pada hari kamis tanggal 10 Desember 1198 M / 9 Shafar 595 H, di Marrakesh dalam usia 72 tahun menurut perhitungan Masehi dan 75 tahun menurut perhitungan tahun Hijriah (Hamzah dan Wa Muna, 2018, 173). Kemudian jenazah Ibnu Rusyd dipindahkan ke Kordova (Hitti, 2018, 742)

\section{Tragedi Pembunuhan Faraq Fouda}

Nama lengkap Faraq Fouda ialah Faraq Ali Fouda. Namanya sering ditulis sebagai Faraq Fouda, Faraj Foda, Faraj Fowda. Faraq Fouda lahir 
di Danietta yang berlokasi dekat Delta Nil, pada tanggal 20 Agustus 1945 (Kontributor Wikipedia, 2018) Faraq Fouda memiliki empat orang anak, yaitu dua orang putra dan dua orang putri. Dalam Pendidikan formalnya, Faraq Fouda memperoleh gelar Sarjana pertanian tepatnya pada tahun 1967. Kemudian pada tahun 1975, Faraq Fouda meraih gelar Master of Science dalam bidang ilmu pertanian. Selanjutnya pada tahun 1981 Faraq Fouda menerima gelar Ph.D dalam bidang ilmu ekonomi pertanian dari Universitas Ain, Syams. (Fouda, 1992, 127)

Faraq Fouda dikenal sebagai sosok pemikir, penggiat hak asasi manusia, serta menjadi komentator sosial. Selain itu Faraq Fouda juga aktif dalam dunia akademisi, ia mengajar di Universitas Ain Syams (Madani, 2014, 43) Faraq Fouda juga pernah berafiliasi dalam partai politik, seperti Partai Wafd dan Partai Istiqlal (Fouda, 2012, ix) Namun pada tahun 1984, Faraq Fouda memutuskan untuk keluar dari Partai Wafd setelah mereka melakukan kerja sama dengan Ikhwanul Muslimin dalam pemilihan perlemen, kemudian setelah memutuskan keluar dari Parta Wafd Faraq Fouda mendirikan sebuah partai yang bernama Mustaqbal (Bakr, 2013)

Mengenai karya-karya Faraq Fouda, ia memiliki beberapa karya yang telah diterbitkan menjadi buku, seperti karya Al-Haqiqah al-Ghaibah, Faraj Fouda wa al-Ma'arikuhu alSiyasiyyah, Al-Wafdu wa alMustaqbal, Qabla al-Syuquth, Hiwar Hawla al-'Almaniyyah, al-Mal'ub, an-Nazir, al-Irhab, dan juga berbagai artikel dalam yang dimuat dalam majalah mingguan Mesir October. Karya Faraq Fouda yang paling menonjol yaitu Al-Haqiqah alGhaibah. Meskipun Faraq Fouda menghasilkan berbagai karya, namun hingga saat ini buku-buku karya Faraq Fouda masih dilarang beredar karena dianggap sangat mengkhawatirkan untuk dibaca oleh masyarakat luas dan memuat informasi-informasi yang bertentangan dengan agama (Madani, 2014, 46)

Sebagaimana yang telah dijelaskan di atas, bahwasanya karyakarya Faraq Fouda dilarang beredar di Mesir bahkan di beberapa negara. Hal tersebut diakibatkan oleh kontroversi yang terdapat dalam beberapa karya Faraq Fouda. Salah satu karya Faraq Fouda yang sangat kontroversi bahkan dinilai sebagai ekstrem yaitu al-Haqiqah al-Ghaibah. Di dalam karyanya tersebut, Faraq Fouda mengkritik politik Islam klasik dan juga pemerintahan-pemerintahan Islam klasik. Karya tersebut juga yang akan menjadi awal tragedi pembunuhan terhadapnya, karena karya Faraq Fouda yang berjudul alHaqiqah al-Ghaibah tersebut dianggap telah menghujat agama Islam dan Faraq Fouda dicap sebagai murtad.

Meskipun demikian, di dalam bukunya, Faraq Fouda telah menjelaskan secara tegas bahwa "Perbincangan yang terdapat di dalam buku ini merupakan perbincangan mengenai sejarah, politik dan pemikiran, bukan perbincangan tentang agama, keimanan dan keyakinan. Ini 
merupakan perbincangan tentang umat Islam, dan bukan tentang agama Islam itu sendiri"(Fouda 2012, 3) Meskipun begitu, Faraq Fouda telah mengetahui bahwa karyanya tersebut akan menjadi perbincangan yang akan dihindari oleh semua orang. Karena kebanyakan orang hanya ingin mendengarkan dan mengetahui apa-apa yang mereka sukai (Fouda, 2012, 1)

Sebagaimana diketahui, bahwasanya Faraq Fouda merupakan salah satu tokoh sekulerisme di Mesir. Dalam pemikirannya, Fouda menentang keras penerapan syari'at Islam di Mesir. Menurut Faraq Fouda, keadilan tidak akan terwujud dengan kebajikan penguasa sematamata dan juga tidak akan bersemi dengan kebajikan rakyat dan penerapan syari'at. Keadilan akan dapat terwujud dengan sistem ketatanegaraan (nidham al-hukm). Maksudnya adalah ketentuanketentuan yang memuat tata cara mengontrol penguasa jika ia bersalah, dan menghambatnya untuk melampaui kewenangannya. Selain itu menurut Faraq Fouda penerapan syari'at Islam itu sendiri sesungguhnya bukanlah esensi dari agama Islam, yang lebih penting dari penerapan syari'at ialah menetapkan ketentuan-ketentuan ketatanegaraan yang adil dan sesuai dengan semangat Islam itu sendiri. Kemudian menurut Faraq Fouda, masyarakat harus dapat membedakan antara dua perkara, yaitu antara perkara melarikan diri dari kenyataan atau menghadapinya, antara kenekatan dan keberanian, antara menonjolkan kulit luar dan menelisik inti terdalam. Masyarakat tidak akan berubah dan umat Islam tidak akan maju apabila hanya memanjangkan jenggot dan mencukur kumis. Islam tidak akan dapat menaklukan zaman dan maju ke depan apabila pemudanya hanya menggunakan pakaian gamis atau jubah. Menjemput kemajuan ilmu pengetahuan tidak akan terjadi apabila hanya dengan menggunakan siwak untuk mengganti pasta gigi, atau hanya sekedar mencelak mata dan menggunakan tangan telanjang ketika makan. (Fouda, 2012, 39-48)

Bagi Faraq Fouda, orang yang berupaya menerapkan syari'at Islam dalam suatu negara ialah kelompok yang membenci masyarakat. Oleh karena itu masyarakat umum pun berhak membalas kebencian mereka. Masyarakat juga berhak mengolokolok mereka seperti mereka mengumbar sumpah serapah kepada masyarakat. Seperti halnya mereka merendahkan masyarakat dengan ungkapan jahiliyah, maka masyarakat pun berhak mencela mereka dengan ungkapan kaum fanatis dan berpikiran sempit. Mereka menempatkan diri mereka sebagai pemuka masyarakat. Padahal mereka lebih tepat diperlakukan sebagai orang-orang tersisih. Mereka telah memperburuk citra Islam dengan cara berpikir mereka yang sempit, karena sikap mereka Islam dianggap sebagai agama kaum fanatis, padahal Islam adalah agama kaum lapang dada. Mereka membuat sempit agama Islam, padahal sebenarnya agama Islam merupakan agama yang terbuka untuk alam dan ilmu pengetahuan. (Fouda, 2012, 50)

Selain melakukan kritik terhadap kelompok yang mendukung 
penerapan syari'at Islam dalam negara, Faraq Fouda juga menjelaskan bagaimana sisi kelam perpolitikan Islam pada masa klasik. Di dalam karyanya, Faraq Fouda menjelaskan bagaimana kisah terbunuhnya sahabat Nabi yaitu Usman bin Affan. Fouda menjelaskan bahwa Usman telah membuat wibawanya tergunjang di mata rakyat, sehingga membuat sebagian masyarakat memutuskan untuk menghunuskan pedang kepadanya, bahkan Usman bin Affan dihina dengan sebutan Na'stal (sebutan untuk orang Kristen Madinah). Tidak hanya masyarakat, namun Usman juga ditentang oleh sebagian para sahabat, hal ini menunjukan bahwa Usman bin Affan telah keluar dari ketentuan-ketentuan Al-Qur'an dan Sunnah. Menurut Faraq Fouda, Umar dan Usman sama-sama mati akibat dibunuh, namun kematian Usman terjadi di tangan umat Islam yang kala itu melakukan pemberontakan dan pengepungan di rumah Usman. Tidak hanya itu, kematian Usman telah melegakan hati umat Islam, bahkan mayat Usman harus bertahan dua malam karena tidak dapat dikuburkan yang kemudian dikuburkan di Hisy Kaukab (pemakaman kaum Yahudi). Dalam riwayat lain bahkan dikatakan, ketika mayat Usman berada di sebuah pintu, Umair bin Dzabi'i datang meludahi mayat Usman lalu kemudian ia mematahkan salah satu persendiannya, dan dalam riwayat lain dikatakan, tatkala prosesi penguburan Usman di Hisy Kaukab berlangsung, orang-orang Islam melemparinya dengan batu sampaisampai para penandunya mesti berlindung di sebuah tembok.
Tragedi yang demikian menurut Faraq Fouda pasti telah disebabkan oleh kemarahan yang teramat besar dan hal tersebut tentu terjadi akibat sistem pemerintahan yang dilakukan oleh Usman bin Affan. Namun bagi Fouda, hal tersebut tidak akan pernah mempengaruhi Islam sama sekali, karena Usman hanyalah pemeluk agama dan ia bukan salah satu rukun dari rukun-rukun Islam, ia hanyalah manusia yang tentu bisa salah. (Fouda, 2012, 34-38)

Selain itu, Faraq Fouda juga menjelaskan bagaimana sisi kelam perpolitikan Islam pada masa Dinasti Umayyah dan Dinasti Abbasiyah. Sisi kelam perpolitikan Dinasti Umayyah dapat dilihat dari tiga penguasa Umayyah yaitu Yazid bin Muawiyah, Yazid bin Abdul Malik dan al-Walid bin Yazid. Nama Yazid bin Muawiyah sangat terkenal lantaran kasus pembunuhannya terhadap Husein bin Ali bin Abi Thalib. Sejarah menyebutkan bagaimana bala tentara Yazid menyerang kota Madinah karena penduduk Madinah mencabut baiat kepadanya. Pada saat penyerangan tersebut panglima perang Yazid yang bernama Muslim bin Uqbah memaklumatkan anarkisme di kota Madinah selama tiga hari. Menurut riwayat, penyerangan tersebut mengakibatkan terbunuhnya sekitar 4.500 jiwa, 1000 perawan diperkosa dan penjarahan terhadap harta, hewan ternak dan senjata masyarakat kota Madinah. Selain itu, penduduk Madinah juga dijadikan budakbudaknya Yazid bin Muawiyah.

Kemudian terkait khalifah Yazid bin Abdul Malik, dalam satu riwayat 
dikatakan bahwa Abdul Malik pernah diminta untuk memutuskan suatu perkara sembari diajukan kepadanya sebongkah mushaf Al-Qur'an, akan tetapi Abdul Malik justru mencampakkannya seraya berkata "ini adalah persentuhan terakhirku denganmu". Abdul Malik merupakan salah seorang tokoh yang sangat hebat dalam ilmu fikih, dan ia merupakan negarawan besar atas apa yang telah dicapainya selama memerintah Dinasti Umayyah. Namun di balik nama besarnya tersebut juga terdapat berbagai sisi kelamnya selama memerintah. Menurut Faraq Fouda, selama Abdul Malik menjadi khalifah, ia memenuhi pemerintahannya dengan lautan makna, nikmatnya dunia, minuman keras, degradasi moral, dan empat tahun kebejatan.

Beralih dari Abdul Malik, sisi kelam perpolitikan Islam menurut Faraq Fouda juga terdapat dalam pemerintahan al-Walid bin Yazid. Dalam pemerintahannya, al-Walid melakukan kegilaan yang bahkan belum pernah dilakukan oleh khalifah sebelumnya maupun terkemudian. Al-Walid sangat terkenal akan kegilaannya, kegemarannya dalam bermabuk-mabukan,

homoseksualitasnya dan bahkan memiliki hobi memanah Al-Qur'an. Bahkan dalam suatu riwayat dikatakan bahwa sesungguhnya alWalid telah menjadi ateis. Semua kejahatan dan degradasi moral yang terjadi di antara para khalifah di atas, tidak lepas dari pengaruh kekuasaan, dengan kekuasaan para khalifah telah mendapatkan dua sayap untuk terbang, yaitu uang dan kekuasaan. (Fouda, 2012, 130-148)
Kemudian sisi kelam perpolitikan pada Dinasti Abbasiyyah menurut Faraq Fouda dimulai dari figur pendirinya yaitu Abu Abbas alSaffah (Si Penjagal). Pada awal kepemimpinannya, al-Saffah mengeluarkan titahnya untuk mencari kuburan dan memburu apa yang tersisa dari jenazah para pemimpin Dinasti Muawiyyah, melecut, menyalib, membakar dan menabur abunya ke udara. Selain itu, al-Saffah juga memerintahkan untuk mencari seluruh sanak keluarga dan pendukung Bani Umayyah, lalu membunuhnya kecuali anak-anak yang masih menyusui. (Fouda, 2012, 159-160)

Atas kritikan dalam karyanya tersebut, Faraq Fouda menjadi sasaran takfir dari berbagai pihak. Mereka menganggap apa yang dijelaskan oleh Faraq Fouda di dalam karyanya tersebut telah membuat dirinya keluar dari Islam dan darahnya halal untuk dibunuh. Meskipun di lembaran awal karyanya Faraq Fouda menjelaskan, bahwa apa yang dijelaskan di dalam bukunya tersebut ialah perbincangan mengenai sejarah, politik dan pemikiran, bukan perbincangan tentang agama, keimanan dan keyakinan. Ini merupakan perbincangan tentang umat Islam, dan bukan tentang agama Islam itu sendiri. Namun argumen tersebut tidak dapat menyelamatkan Faraq Fouda dari tragedi pembunuhan yang menimpanya.

Tragedi pembunuhan terhadap Faraq Fouda terjadi pada tanggal 8 Juni 1992 (Kontributor Wikipedia, 2018), beberapa hari sebelum Fouda dibunuh tepatnya pada tanggal 3 Juni, 
sekelompok ulama dari Universitas al-Azhar mengeluarkan pernyataan bahwa, berdasarkan pemikiran dan tulisannya yang berjudul al-Haqiqah al-Ghaibah Faraq Fouda telah menghujat agama Islam dan karena itu ia telah keluar dari agama Islam. Hal tersebut berarti Fouda telah menjadi musuh Islam dan darahnya halal dibunuh. Para pendukung Faraq Fouda menggambarkan bahwa pernyataan tersebut yang membuat nama Faraq Fouda berada di urutan pertama sebagai orang yang memusuhi Islam sebagai "hasutan untuk membunuh" Fouda. Kemudian lima hari setelah pernyataan tersebut keluar, dua orang anggota kelompok militan Islamis (al-Jama'at alIslamiyya) memasuki kantor Fouda dan kemudian menembaknya hingga tewas dan menyebabkan putra Faraq Fouda serta beberapa orang lainnya mengalami luka parah. Setelah penembakan tersebut, pemimpin Ikhwanul Muslimin, Ma'mun alHudaybi menjadi salah satu orang yang pertama menyambut dan membenarkan pembunuhan tersebut. Ulama al-Azhar dan Muhammad alGhazali bersaksi bahwa ketika negara gagal untuk menghukum orang murtad, maka orang lain harus melakukannya. (Soage, 2007, 30-31)

\section{Analisis Terhadap Tragedi Intelektual dalam Islam}

Islam merupakan agama yang rahmatan lil 'alamin, oleh karena itu setiap pemeluk agama Islam harus dapat mewujudkan nilai-nilai keIslaman tersebut kepada seluruh makhluk ciptaan Tuhan. Konsep Rahmatan lil 'alamin tidak hanya diwujudkan untuk satu kelompok atau satu golongan saja, akan tetapi kepada seluruh penghuni alam semesta. Karena Islam itu bersifat universal dan bukan bersifat partikular, kemudian sudah seharusnya umat Islam menerima setiap perbedaan dan hal-hal baru demi terwujudnya suatu tatanan kehidupan yang lebih baik, selama perubahan dan perbedaan yang terjadi tidak menyangkut hal-hal pokok.

Intelektual sebagai hasil dari berpikir sangat dianjurkan di dalam Islam, hal tersebut dapat dilihat dari dorongan ayat Al-Qur'an yang memerintahkan umat Islam untuk selalu berpikir, di antara ayat tersebut adalah, kata yang berasal dari 'aqala yang mengandung arti mengerti, memahami, dan berpikir, terdapat lebih dari 54 ayat di dalam AlQur'an, di antaranya pada surat AlBaqarah: 242, Al-Anfal: 22 dan AlNahl: 11-12. Kemudian kata yang berasal dari nazhara yang mengandung arti melihat secara abstrak dalam artian berpikir dan merenungkan atau menalar, kata tersebut terdapat lebih dari 30 ayat, di antaranya pada surat Qaf: 6-7, AlThariq: 5-7. Kemudian kata yang berasal dari tafakkara yang mengandung arti berpikir, kata tersebut terdapat 16 ayat di dalam AlQur'an, di antaranya pada surat AlNahl: 68-69, dan Al-Jasiyah: 12-13. Kemudian ayat yang berasal dari kata ulu al-bab yang mengandung arti orang yang berpikir. Ayat yang berasal dari kata ulu al-ilm yang mengandung arti orang yang berilmu. Ayat yang berasal dari kata ulu alabshar yang mengandung arti orang yang mempunyai pandangan. Ayat yang berasal dari kata ulu al-Nuha 
yang mengandung arti orang bijaksana.

Melihat dorongan ayat AlQur'an tersebut dapat dipahami bahwa Islam sangat menganjurkan untuk berpikir dan menjadi sosok intelektual. Oleh karena itu, perbedaan yang terjadi antara golongan intelektual dengan golongan agamawan, harus menjadi warna di dalam Islam dan bukan menjadi alasan untuk saling menyalahkan, menindas, bahkan saling membunuh. Menjadi rasional ataupun tradisional bukanlah suatu kesalahan, yang menjadi kesalahan ialah ketika menganggap apa yang diyakini ataupun cara yang digunakan merupakan satu-satunya jalan untuk mencapai sesutau.

Kemudian di balik permasalahan yang terjadi antara golongan intelektual dan golongan agamawan, selalu memiliki sisi politis. Sisi politis tersebut yang kemudian akan menimbulkan kekerasan dalam kehidupan, karena watak dasar politik ialah berujung pada kekerasan. Hal demikian juga seperti yang menimpa tragedi nakbah Ibnu Rusyd dan tragedi pembunuhan Faraq Fouda. Oleh karena itu, umat Islam harus dapat bersikap bijak dalam menerima setiap perbedaan. Perbedaan diperbolehkan selama tidak merubah hal-hal pokok dalam Islam. Persoalan mana yang salah dan mana yang benar itu bersifat relatif, di satu sisi suatu pandangan dapat terlihat salah dan di satu sisi lainnya juga dapat terlihat benar, oleh karena itu bersikap saling toleran dalam menerima perbedaan sangatlah penting. Kemudian persoalan siapa yang kafir atau yang pantas masuk surga dan neraka menjadi tugas mutlaknya Allah, oleh karena itu serahkan semuanya kepada Allah dan biarkan Allah sendiri yang menilainya apakah seseorang itu pantas dihukum atau pantas menerima pahala.

\section{KESIMPULAN}

Islam telah hadir sejak 1400 tahun yang lalu, selama perkembangan tersebut yaitu dari awal hingga saat ini, telah terjadi berbagai tragedi di dalam Islam, salah satunya yaitu tragedi intelektual. Islam merupakan agama yang rahmatan lil' alamin, oleh karena itu Islam tidak pernah mengajarkan untuk melakukan kekerasan, hanya saja sebagian orang gagal dalam memahami Islam itu sendiri sehingga munculnya kekerasan bahkan berujung pada pembunuhan. Kegagalan dalam memahami seringkali terjadi karena menganggap apa yang diyakini ataupun cara yang digunakan merupakan "satu-satunya" jalan untuk mencapai sesutau.

Islam telah hadir sejak 1400 tahun yang lalu, selama perkembangan tersebut yaitu dari awal hingga saat ini, telah terjadi berbagai tragedi di dalam Islam, salah satunya yaitu tragedi intelektual. Islam merupakan agama yang rahmatan lil' alamin, oleh karena itu Islam tidak pernah mengajarkan untuk melakukan kekerasan, hanya saja sebagian orang gagal dalam memahami Islam itu sendiri sehingga munculnya kekerasan bahkan berujung pada pembunuhan. Kegagalan dalam memahami 
seringkali terjadi karena menganggap apa yang diyakini ataupun cara yang digunakan merupakan "satu-satunya" jalan untuk mencapai sesutau.

Tragedi nakbah Ibnu Rusyd merupakan suatu tragedi pengusiran ataupun pengasingan terhadap Ibnu Rusyd dan murid-muridnya, hal itu terjadi karena tuduhan-tuduhan yang dilontarkan oleh kaum agamawan dan para kaum elit masyarakat yang tidak menyukai dan membenci Ibnu Rusyd. Akibat tragedi tersebut, sebagian karya-karya filsafat Ibnu Rusyd dibakar dan dimusnahkan. Kemudian awal terjadinya tragedi nakbah Ibnu Rusyd yaitu terjadi ketika para kelompok agamawan membawa lembaran yang berisi komentarkomentar Ibnu Rusyd terhadap karya

\section{Daftar Kepustakaan}

Ahmad, Abdul Fattah Sayyid. 2005. Tasawuf Antara Al-Ghazali Dan Ibnu Taimiyah. Jakarta: Khalifa.

Aksin Wijaya. 2018. Dari Membela Tuhan Ke Membela Manusia: Kritik Atas Nalar Agamaisasi Kekerasan. Bandung: Mizan.

Al-Jabiri, Muhammad 'Abid. 2003. Al-Mutsaqqafuna $\mathrm{Fi} \quad \mathrm{Al}$ Hadharah Al-Arabiyah: Mihnah Ibn Hanbal Wa Naqbah Ibn Rusyd. Yogyakarta: Pustaka Alief.

Amin, Ahmad. 1936. Dhuha AlIslam. Kairo: Maktabah alNahdah al-Mishriyah. filsafat Aristoteles untuk ditunjukkan kepada khalifah Ya'qub al-Manshur, karena menurut mereka komentar tersebut telah membuat Ibnu Rusyd keluar dari Islam.

Sedangkan tragedi pembunuhan Faraq Fouda terjadi karena ulamaulama al-Azhar menilai bahwa Faraq Fouda telah keluar dari Islam akibat dari pemikirannya yang tertuang dalam karyanya yang berjudul alHaqiqah al-Ghaibah. Atas pemikirannya tersebut, Faraq Fouda dinilai telah menghujat agama Islam oleh karena itu ia telah menjadi murtad dan darahnya halal untuk dibunuh. Pernyataan dari ulama tersebut yang kemudian mendorong dua orang fundamentalis untuk membunuh Faraq Fouda.

Anwar, Khoirul. 2019. "Maqashid Asy-Syari'ah Menurut Ibnu Rusyd." Jurnal Pemikiran Hukum Islam Vol. 1(1).

Asy-Syahrastani. 2003. Al-Milal Wa Al-Nihal: Aliran-Aliran Teologi Dalam Sejarah Umat Manusia. Surabaya: Bina Ilmu.

Bakr, Sara Abou. 2013. "Faraq Fouda: Assassination of The World." Daily News Eqypt. https://dailynewsegypt.com/2 013/06/08/farg-foudaassassination-of-the-word/ (February 21, 2021).

Drajat, Amroeni. 2006. Filsafat Islam: Buat Yang Pengen Tahu. Jakarta: Erlangga. 
Faiz, $\quad$ Fahruddin.

"KEKERASAN

INTELEKTUAL

ISLAM

TERHADAP PERISTIWA MIHNAH MU'TAZILAH)." ESENSIA: Jurnal Ilmu-Ilmu Ushuluddin.

Fakhry, Majid. 1986. Sejarah Filsafat Islam. Jakarta: Pustaka Jaya.

Faturohman. 2016. "Ibnu Rusd Dan Pemikirannya." TSARWAH: Jurnal Ekonomi dan Bisnis Islam Vol. 1(1).

Fitrianah, Rossi Delta. 2018. "IBNU RUSYD (AVERROISME) DAN PENGARUHNYA DIBARAT." EL-AFKAR : Jurnal Pemikiran Keislaman dan Tafsir Hadis.

Fouda, Faraq. 1992. Al-Irhab. Kairo: Al-Mathabi' al-Haiah alMishriyah al-'Ammah Lil Kitab.

—. 2012. Al-Haqiqah AlGhaibah. Jakarta: Democracy Project.

Halimatuzzahro. 2017. "Filsafat Politik Ibnu Rusyd." Jurnal filsafat.

Hassan Hanafi dan Muhammad 'Abid Al-Jabiri. 2015. Hiwar AlMasyriq Wa Al-Maghrib: Talihi Silsilah Al-Rudud Wa Al-Munaqasat. Yogyakarta: IRCiSoD.

Hitti, Philip Khuri. 2018. History of The Arabs; From the Earliest Times to the Present. Jakarta: Penerbit Zaman.
Khan, Ali Mahdi. 2004. The Elements of Islamic Philosophy. Bandung: Nuansa.

Kontributor Wikipedia. 2018. "Faraq Fouda." Wikipedia. https://id.wikipedia.org/wiki/F arag_Foda (February 21, 2021).

M.M Syarif. 1991. History of Muslim Philosophy. Bandung: Mizan.

Madani, Alex. 2014. "Studi Analisis Pandangan Farag Fouda Tentang Hubungan Agama Dan Negara Dalam Siyasah Syar'iyyah." Pascasarjana IAIN Sumatera Utara.

Madani, Mohamad Thoyyib. 2017. "Ibnu Rusyd Dan Kontribusi Pemikirannya Terhadap Perkembangan Ilmu Fiqih." KABILAH : Journal of Social Community.

Madjid, Nurcholis. 1997. Kaki Langit Peradaban Islam. Jakarta: Paramadina.

Mashar, Aly. 2013. "Falsafah Kalam Ibnu Rusyd: Melacak Sisi 'Mutiara' Yang 'Hilang."' Tribakti: Jurnal Pemikiran Keislaman 24(No. 1).

Mubit, Rizal. 2016. "Pembelaan Ibnu Rusyd Terhadap Pemikiran Filosof." Jurnal Miyah Vol. XI(1).

Rusyd, Ibnu. 2015. Fashl Al-Maqal Fi Ma Baina Al-Hikmah Wa Al-Syari'ah. Yogyakarta: Kalimedia. 
Said, Edward W. 2014. Peran Thaha, Ahmadi. 1982. Ibnu Intelektual. Jakarta: Pustaka Taimiyyah: Hidup Dan Obor Indonesia.

Seyyed Hossein Nasr. 2003. Islam: Religion, History, and Civilization. Surabaya: Risalah Gusti. Pikiran-Pikirannya. Surabaya: Bina Ilmu.

Urvoy, Dominique. 2000. Perjalanan Intelektual Ibnu Rusyd. Surabaya: Risalah Gusti.

Seyyed Hossein Nasr dan Oliver Leaman. 2003. Ensiklopedi Tematis Filsafat Islam. Bandung: Mizan.

Soage, Ana Belen. 2007. "Faraj Fawda, or The Cost of Fredom of Expression." Middle East Review of International Affairs Vol. 11(2).

Zah, Ham. 2018. "EPISTEMOLOGI IBNU RUSYD DALAM MEREKONSILIASI AGAMA DAN FILSAFAT (Ibn Rushd's Epistemology in The Reconciliation of Religion and Philosophy)." Jurnal Pemikiran Islam.

Zar, Sirajuddin. 2014. Filsafat Islam: Filosof Dan Filsafatnya. Jakarta: Rajawali Pers. 